\begin{tabular}{|l|c|c|c|r|}
\hline $\begin{array}{l}\text { Cuadernos de Investigación Geográfica } \\
\text { Geographical Research Letters }\end{array}$ & 2017 & N $^{\circ} 43(1)$ & pp. 7-17 & $\begin{array}{r}\text { ISSN 0211-6820 } \\
\text { eISSN 1697-9540 }\end{array}$ \\
\hline
\end{tabular}

\title{
EXPERIMENTS AS TOOLS IN GEOMORPHOLOGY
}

\section{SEEGER}

Physical Geography, Trier University, D54286 Trier, Germany.

\begin{abstract}
In this introductory article to the special issue "Experiments in geomorphology", the fundamentals of experiments in science, and especially in earth science and geomorphology, are discussed. This is of special interest, as geomorphological sciences crosses scales and thus, different types of experiments are applied for highly variable tasks: (i) Real experiments: to test hypotheses on the process interaction of well defined landscape components; (ii) Quasi experiments: the integrated response of pre-defined morphological units is quantified here; (iii) Hybrid experiments: spatial stratification of the landscape according to statistically evaluable characteristics. A short review on different types of experiments in geomorphology is given, focusing on the processes relevant for soil erosion: splash, inter-rill and linear erosion. Finally, the contributions to the special issue are classified according to the classification of experiments given.
\end{abstract}

\section{Los experimentos como herramientas en geomorfología}

RESUMEN. A modo de introducción del número especial dedicado a "experimentos en geomorfología”, el presente artículo discute de forma breve la experimentación en Ciencias de la Tierra, y especialmente en el campo de la geomorfología. En este caso, la experimentación se hace especialmente compleja, ya que la geomorfología cruza deferentes escalas y en consecuencia, muy diferentes tipos de experimentos han de ser desarrollados y aplicados: (i) Experimentos reales: en los cuales se analizan hipótesis sobre la interacción de procesos en unidades de paisaje bien definidas; (ii) Cuasi experimentos: se cuantifica la respuesta integral de unidades geomorfológicas pre-definidas; (iii) Experimentos híbridos: con estratificación espacial del paisaje según características analizables de forma estadística. También incluye un breve repaso de diferentes tipos de experimentos, centrándose en aquellos dedicados al análisis de los procesos relacionados con la erosión del suelo. Y finalmente, las contribuciones al número especial son revisadas y catalogadas según la clasificación mencionada anteriormente.

Key words: experiments, soil erosion, experimental theory, experimental classification, soil erosion measurements. 
Palabras clave: experimentos, erosión de suelo, teoría de la experimentación, clasificación de experimentos, medición de la erosión.

Received: 21 December 2016

Accepted: 2 February 2017

* Corresponding author: Manuel Seeger, Physical Geography, Trier University, D54286 Trier, Germany. E-mail: seeger@uni-trier.de

\section{Introduction}

Experiments are considered to be the most important empirical method in natural sciences. But whilst the observation of natural processes was predominant in ancient times, there has been a development of experimental sciences from mid-17th century (Radder, 2009). Nobel laureate Hannes Alfvén even stated that "We have to learn again that science without contacts with experiments is an enterprise which is likely to go completely astray into imaginary conjecture" (cited by Lundin, 2001). Within Earth science, for more than 100 years experiments have been used to understand the process-response systems of functional geomorphology (Bagnold, 1938; Chepil, 1945; Einstein, 1936; Wollny, 1879). On their basis, fundamentals of process identification and description as well as on experimental design have been defined. But it was only after stating that actual erosion rates exceed soil formation rates by up to 10 times when it became clear that geomorphological research has to shift from a merely descriptive science to a quantitative and experimental scientific approach (Slaymaker, 1991a).

Experiments always contain elements of manipulation and intervention, which make them reproducible (Radder, 2009), and thus allow to reduce the "noise" of the environment (Ahnert, 1980) and to introduce any kind of boundary condition for the phenomena under observation (Bockheim and Gennadiyev, 2009). A very systematic approach is needed therefore not only in defining the problem and proposing the precise questions, or setting up the appropriate hypothesis (Kuhn et al., 2014; Otto and Mönter, 2015), which helps to reduce the complexity of experiments. But also a deep understanding of the interactions of the experiment with its environment: the researcher has to identify and be aware if the interaction is necessary, irrelevant or forbidden for a successful experiment that produces the desired results (Radder, 2009).

\section{Experiments in geomorphology}

This led to a vivid discussion within the last decades of the $20^{\text {th }}$ century, where Ahnert (1980) defended on one side this very strict view on experiments, criticizing that the IGU Commission on Field Experiments was still only talking about measurements - thus putting geomorphology at a level of ancient science of mere observation of nature. On the other side, his position was objected as it was considered that the requested manipulation of the geomorphological system would deliver only artifacts of the experimental setup results, instead of real system observations (Slaymaker, 1991b). 
According to this, and the certainty that within geomorphological systems it is difficult to isolate, manipulate and alter system components, three different types of experiments have to be defined, according to their goals, experimental setup and level of abstraction and definition (Kuhn et al., 2014; Slaymaker, 1991b; Slaymaker et al., 1982):

(i) Real experiments: to test hypotheses on the process interaction of well-defined landscape components. They need:

a) strictly controlled field conditions,

b) strict boundaries for defining mass and energy balances,

c) the spatio-temporal conditions and characteristics of the natural system are well known.

They allow a clear and high level of falsification of the hypothesis

(ii) Quasi experiments: the integrated response of pre-defined morphological units is quantified here and:

d) pre-defined knowledge is required about the targeted morphological units,

e) the experimental framework is embedded within the magnitude-frequency limits of the morphologically active events,

f) morphological knowledge replaces a strict and formal experimental design.

(iii) Hybrid experiments: based on the spatial stratification of the landscape according to statistically evaluable characteristics. They are based on:

g) spatial stratification of landscape units to be tested,

h) reduced extent of parameter control,

i) system-based conditions of framework.

Classical plot type experiments, such as implemented by the USDA in the 40's of the 20th century (Wishmeier and Smith, 1978) have been assigned to the first type of experiments mentioned above (Bryan, 1991), but later findings have shown a wide range of uncertainty of the boundary conditions, resulting in a high variability of supposed identical plots (Nearing et al., 1999). In addition, several studies have proven the dependency of the results on the size of the plots (Boix-Fayos et al., 2006; Cerdan et al., 2004; Smets et al., 2008). An exhaustive and very critical review on the sources of errors has been published by Boix-Fayos et al. (2007) based on 20 years of own measurements. Consequently, plot measurements are for sure quasi-experiments where a wide range of parameters responsible for runoff generation and erosion are outside the experimenter control. Nevertheless, they contributed for a quantitative analysis of soil erosion, regarding different management types (see, among many others, Edwards et al., 2000; Mutchler et al., 1994; Navas et al., 1997; Ries, 1994; Seuffert, 1993). More recently, the results of plot measurements and other methods for measuring soil erosion have been compiled in different studies (Auerswald et al., 2009; Cerdan et al., 2010; García-Ruiz et al., 2015) 
for quantification of regional or continental erosion rates. Despite of the real and long term value of these measurements, many of them have been dismantled during the last decades, leading to a lack of measured values of soil erosion (Stroosnijder, 2005). This trend has been inverted during the last decade, where different types of plot systems have been installed (e. g. Bagarello et al., 2013, 2011, García-Orenes et al., 2010, 2009; León et al., 2015; Rodrigo-Comino et al., 2015, 2016; Todisco et al., 2012). The investigation by Kirchhoff et al. (2017) included in this special issue takes over the need to gain realworld data on soil erosion, combining plot measurements with rainfall simulations.

Anyhow, there have been clear experimental approaches in geomorphology for developing process concepts (Bagnold, 1941; Chepil, 1945; Einstein, 1936; Ekern, 1950), but also for understanding and quantifying the forces that lay behind geomorphological processes (Ali et al., 2013; Becker et al., 2015, Gimenez and Govers, 2002; Govers, 1989; Kinnell, 1993; Luk and Cai, 1990; Marzen et al., 2015; Sidorchuk et al., 2008). But for understanding landscape development, there is a need to recognize and quantify basic principles in geomorphology. To represent this level of abstraction, scaled experiments have been developed, mainly in fluvial morphology (Kleinhans et al., 2010; Postma et al., 2008; Vermeulen et al., 2014; Wallerstein et al., 2001) or mass wasting (Major, 1997; Okuda, 1991). Their benefit for understanding geomorphological systems is widely recognised (Kleinhans et al., 2010; Paola et al., 2009) and has even led to experiments to explain extra-terrestrial geomorphic features (Shinbrot et al., 2004; Védie et al., 2008). Despite their valuable contribution to geomorphological research, examples of scaled experiments are not present in this special issue, as the authors of all articles have concentrated their work on field experiments for quantifying and understanding geomorphological processes on landscapes under a strong human impact.

\section{The topics of this issue}

Regarding soil erosion processes, experiments have been designed to gain information, process knowledge and quantitative insights into the forces affecting the soil surface during soil erosion. Therefore, a wide range of rainfall simulators have been developed (Seyhan, 1977; Shriner et al., 1977) and applied in laboratory research (Geddes and Dunkerley, 1999; Goebes et al., 2014; Kinnell, 2005a, 2005b, 2001, 1985; Lassu et al., 2015; León et al., 2014; McGregor et al., 1988; Poesen and Lavee, 1991; Slattery and Bryan, 1994). The development and application of rainfall simulators in the field has opened new insights into soil erosion research (see among many others Arnáez et al., 2007; Butzen et al., 2015, 2011, Cerdà et al., 1998, 1995; Cerdà, 1998; Cerdà and Jurgensen, 2011; Imeson et al., 1998; Seeger, 2007). But here, one major problem is still unsolved, which was already mentioned by Bryan and De Ploey (1983): the missing standardisation of rainfall simulators, experimental procedures and principles of measurement of the experiments results. Despite the efforts done within the last years (Iserloh et al., 2013a, 2013b; Ries et al., 2009), there is still a lack in the methodological development of rainfall simulations (Ries et al., 2013). The article provided by Zemke (2017) in this issue will add some valuable information on the issues of rainfall simulation methodology still in debate. 
In addition to the article of Kirchhoff et al. (2017) mentioned above, Iserloh et al. (2017) provide a very holistic view of erosion processes at different scales, which includes a clear landscape stratification, and thus corresponds to hybrid experiments as described in advance. This approach, which consists of handling the different scales in which erosion and geomorphological processes are effective and visible, is also followed within the contribution of Ferrer et al. (2017). The contributions by Arnáez et al. (2017) and Regüés et al. (2017) to this issue are clearly in the focus of the debate described previously, discussing if we are confronted with mere measurements and observations. In my opinion, the measurement of soil infiltration under different land uses is a clear experimental approach to the process of water supply into soils, as the results are as variable as the methods that have been developed until now (Hills, 1971; Mertens et al., 2002; Sidiras and Roth, 1987; Šimůnek et al., 1999). Thus, they are subject to uncertainty of the results and their interpretation in the same manner as the rainfall simulations. In addition, global change can be addressed as a large-scale experiment, in which the boundary conditions of the landscape as a laboratory are changed deliberately. This provides the unique possibility to observe and quantify emerging geomorphological processes, such as terrace collapses.

The paper submitted by Masselink et al. (2017) can be seen in a similar way, as it observes natural processes in an unaltered agricultural system. Anyhow, this paper deserves a special mention as it tackles the concept of connectivity in erosion research. This has been discussed for some time (Borselli et al., 2008; Cammeraat, 2002; Cerdan et al., 2004; Darboux et al., 2002; de Vente and Poesen, 2005; Lehmann et al., 2007; Mueller et al., 2007; Okin et al., 2009), but never applied, and quantified in an experimental way under the natural conditions of an agricultural landscape.

Contrasting with the contributions presented above, the approach of Pavelka et al. (2017) provides an experiment sensu stricto, as the influencing factors for soil translocation during soil tillage are clearly identified and controlled. In addition, this experimental approach bridges across disciplines, as it connects the investigation on the usability of different Neolithic ploughs and its effects on the soils.

\section{Conclusions}

This issue of Cuadernos de Investigación Geográfica is not able to come across the different types of all possible experiments in geomorphology, and even less to solve methodological and conceptual discussions on the applicability of experiments in soil erosion research and geomorphology. But the contributions clearly show that experiments are still needed to understand the processes that shape our world. Also these new technological and methodological developments have to be taken into account and applied by geomorphologists because a wide range of understanding of the processes we observe is still missing.

\section{References}

Ahnert, F. 1980. A note on measurements and experiments in geomorphology. Zeitschrift für Geomorphology Supplementband 35, 1-10. 
Ali, M., Seeger, M., Sterk, G., Moore, D. 2013. A unit stream power based sediment transport function for overland flow. Catena 101, 197-204. http://doi.org//10.1016/j.catena. 2012.09.006.

Arnáez, J., Lana-Renault, N., Ruiz-Flaño, P., Pascual, N., Lasanta, T. 2017. Mass soil movement on terraced landscapes of the Mediterranean mountain areas: A case study of the Iberian Range, Spain. Cuadernos de Investigación Geográfica 43 (1), 83-100. http://doi.org/10.18172/ cig.3211.

Arnáez, J., Lasanta, T., Ruiz-Flaño, P., Ortigosa, L. 2007. Factors affecting runoff and erosion under simulated rainfall in Mediterranean vineyards. Soil and Tillage Research 93, 324-334. http://doi.org/10.1016/j.still.2006.05.013.

Auerswald, K., Fiener, P., Dikau, R. 2009. Rates of sheet and rill erosion in Germany - A metaanalysis. Geomorphology 111, 182-193. http://doi.org/10.1016/j.geomorph.2009.04.018.

Bagarello, V., Ferro, V., Giordano, G., Mannocchi, F., Todisco, F., Vergni, L. 2013. Predicting event soil loss from bare plots at two Italian sites. Catena 109, 96-102. http://doi. org/10.1016/j.catena.2013.04.010.

Bagarello, V., Stefano, C.D., Ferro, V., Kinnell, P.I.A., Pampalone, V., Porto, P., Todisco, F. 2011. Predicting soil loss on moderate slopes using an empirical model for sediment concentration. Journal of Hydrology 400, 267-273. http://doi.org/10.1016/j.hydrol.2011.01.029.

Bagnold, R.A. 1938. Grain structure of sand dunes and its relation to their water content. Nature 142, 403-404.

Bagnold, R.A. 1941. The physics of blown sand and desert dunes. Methuen, London, 265 pp.

Becker, K., Gronz, O., Wirtz, S., Seeger, M., Brings, C., Iserloh, T., Casper, M.C., Ries, J.B. 2015. Characterization of complex pebble movement patterns in channel flow - a laboratory study. Cuadernos de Investigación Geográfica 41, 63-85. http://doi.org/10.18172/cig.2645.

Bockheim, J.G., Gennadiyev, A.N. 2009. The value of controlled experiments in studying soilforming processes: A review. Geoderma 152, 208-217. http://doi.org/10.1016/j.geoderma. 2009.06.019.

Boix-Fayos, C., Martínez-Mena, M., Calvo-Cases, A., Arnau-Rosalén, E., Albaladejo, J., Castillo, V. 2007. Causes and underlying processes of measurement variability in field erosion plots in Mediterranean conditions. Earth Surface Processes and Landforms 32, 85-101. http://doi. org/10.1002/esp.1382.

Boix-Fayos, C., Martínez-Mena, M., Arnau-Rosalén, E., Calvo-Cases, A., Castillo, V., Albaladejo, J. 2006. Measuring soil erosion by field plots: Understanding the sources of variation. Earth-Science Reviews 78, 267-285. http://doi.org/10.1016/j.earscirev.2006.05.005.

Borselli, L., Cassi, P., Torri, D. 2008. Prolegomena to sediment and flow connectivity in the landscape: A GIS and field numerical assessment. Catena 75, 268-277. http://doi.org/10.1016/j. catena.2008.07.006.

Bryan, R., De Ploey, J. 1983. Comparability of soil loss measurements with different laboratory rainfall simulators. Catena Supplement 4, 33-56.

Bryan, R.B. 1991. Surface wash. In: Field Experiments and Measurement Programs in Geomorphology. A.A.Balkema,, Amsterdam, pp. 107-167.

Butzen, V., Seeger, M., Casper, M. 2011. Spatial pattern and temporal variability of runoff processes in Mediterranean Mountain environments - coupling experimental measurement and GIS-analyses. Zeitschrift fúr Geomorphology Supplementband 55, 25-48.

Butzen, V., Seeger, M., Marruedo, A., de Jonge, L., Wengel, R., Ries, J.B., Casper, M.C. 2015. Water repellency under coniferous and deciduous forest - Experimental assessment and impact on overland flow. Catena 133, 255-265. http://doi.org/10.1016/j.catena.2015.05.022.

Cammeraat, L.H. 2002. A review of two strongly contrasting geomorphological systems within the context of scale. Earth Surface Processes and Landforms 27, 1201-1222. http://doi. org/10.1002/esp.421. 
Cerdà, A. 1998. The influence of aspect and vegetation on seasonal changes in erosion under rainfall simulation on a clay soil in Spain. Canadian Journal of Soil Science 78, 321-330.

Cerdà, A., Imeson, A.C., Calvo, A. 1995. Fire and aspect induced differences on the erodibility and hydrology of soils at La Costera, Valencia, southeast Spain. Catena 24, 289-304. http://doi. org/1.1016/0341-8162(95)00031-2.

Cerdà, A., Jurgensen, M.F. 2011. Ant mounds as a source of sediment on citrus orchard plantations in eastern Spain. A three-scale rainfall simulation approach. Catena 85, 231-236. http://doi. org/10.1016/j.catena.2011.01.008.

Cerdà, A., Schnabel, S., Ceballos, A., Gómez-Amelia, D. 1998. Soil hydrological response under simulated rainfall in the Dehesa land system (Extremadura, SW Spain) under drought conditions. Earth Surface Processes and Landforms 23, 195-209. http://doi.org/10.1002/ (SICI)1096-9837(199803)23:3<195::AID-ESP830>3.0.CO;2-1.

Cerdan, O., Govers, G., Le Bissonnais, Y., Van Oost, K., Poesen, J., Saby, N., Gobin, A., Vacca, A., Quinton, J., Auerswald, K., Klik, A., Kwaad, F.J.P.M., Raclot, D., Ionita, I., Rejman, J., Rousseva, S., Muxart, T., Roxo, M.J., Dostal, T. 2010. Rates and spatial variations of soil erosion in Europe: A study based on erosion plot data. Geomorphology 122, 167-177. http:// doi.org/10.1016/j.geomorph.2010.06.011.

Cerdan, O., Le Bissonnais, Y., Govers, G., Lecomte, V., Van Oost, K., Couturier,A., King, C., Dubreuil, N. 2004. Scale effect on runoff from experimental plots to catchments in agricultural areas in Normandy. Journal of Hydrology 299, 4-14. http://doi.org/10.1016/j.hydrol.2004.02.017.

Chepil, W. 1945. Dynamics of wind erosion: I. Nature of movement of soil by wind. Soil Science 60, 305-320.

Darboux, F., Davy, P., Gascuel-Odoux, C. 2002. Effect of depression storage capacity on overlandflow generation for rough horizontal surfaces: water transfer distance and scaling. Earth Surface Processes and Landforms 27, 177-191. http://doi.org/10.1002/esp.312.

de Vente, J., Poesen, J. 2005. Predicting soil erosion and sediment yield at the basin scale: Scale issues and semi-quantitative models. Earth-Science Reviews 71, 95-125. http://doi. org/10.1016/j.earscirev.2005. 02.002.

Edwards, L., Burney, J.R., Richter, G., MacRae, A.H. 2000. Evaluation of compost and straw mulching on soil-loss characteristics in erosion plots of potatoes in Prince Edward Island, Canada. Agriculture, Ecosystems, Environment 81, 217-222. http://doi.org/10.1016/S01678809(00)00162-6.

Einstein, H.A. 1936. Der Geschiebetrieb als Wahrscheinlichkeitsproblem. ETH Zürich, Zürich.

Ekern, P.C. 1950. Raindrop impact as the force initiating soil erosion. Soil Science Society of America Journal 15, 7-10.

Ferrer, V., Errea, P., Alonso, E., Gómez-Gutiérrez, A., Nadal-Romero, E. 2017. A multiscale approach to assess geomorpholgical processes in a semiarid badland area (Ebro Depression, Spain). Cuadernos de Investigación Geográfica 43 (1), 41-62. http://doi.org/10.18172/cig.3139.

García-Orenes, F., Cerdà, A., Mataix-Solera, J., Guerrero, C., Bodí, M.B., Arcenegui, V., Zornoza, R., Sempere, J.G. 2009. Effects of agricultural management on surface soil properties and soil-water losses in eastern Spain. Soil and Tillage Research 106, 117-123. http://doi. org/10.1016/j.still.2009.06.002.

García-Orenes, F., Guerrero, C., Roldán, A., Mataix-Solera, J., Cerdà, A., Campoy, M., Zornoza, R., Bárcenas, G., Caravaca, F. 2010. Soil microbial biomass and activity under different agricultural management systems in a semiarid Mediterranean agroecosystem. Soil and Tillage Research 109, 110-115. http://doi.org/10.1016/j.still.2010.05.005.

García-Ruiz, J.M., Beguería, S., Nadal-Romero, E., González-Hidalgo, J.C., Lana-Renault, N., Sanjuán, Y. 2015. A meta-analysis of soil erosion rates across the world. Geomorphology 239, 160-173. http://doi.org/10.1016/j.geomorph.2015.03.008. 
Geddes, N., Dunkerley, D. 1999. The influence of organic litter on the erosive effects of raindrops and of gravity drops released from desert shrubs. Catena 36, 303-313. http://doi.org/10.1016/ S0341-8162(99)00050-8.

Giménez, R., Govers, G. 2002. Flow detachment by concentrated flow on smooth and irregular beds. Soil Science Society of America Journal 66, 1475-1483. http://doi.org/10.2136/ sssaj2002.1475.

Goebes, P., Seitz, S., Geißler, C., Lassu, T., Peters, P., Seeger, M., Nadrowski, K., Scholten, T., 2014. Momentum or kinetic energy - How do substrate properties influence the calculation of rainfall erosivity? Journal of Hydrology 517, 310-316. http://doi.org/10.1016/j. jhydrol.2014.05.031.

Govers, G. 1989. Grain velocities in overland flow: a laboratory study. Earth Surface Processes and Landforms 14, 481-498. http://doi.org/10.1002/esp.3290140605.

Hills, R.C. 1971. Lateral flow under cylinder infiltrometers: a graphical correction procedure. Journal of Hydrology 13, 153-162. http://doi.org/10.1016/0022-1694(71)90212-5.

Imeson, A.C., Lavee, H., Calvo, A., Cerdà, A. 1998. The erosional response of calcareous soils along a climatological gradient in southeast Spain. Geomorphology 24, 3-16. http://doi. org/10.1016/S0169-555X(97)00097-4.

Iserloh, T., Ries, J.B., Arnáez, J., Boix-Fayos, C., Butzen, V., Cerdà, A., Echeverría, M.T., Fernández-Gálvez, J., Fister, W., Geißler, C., Gómez, J.A., Gómez-Macpherson, H., Kuhn, N.J., Lázaro, R., León, F.J., Martínez-Mena, M., Martínez-Murillo, J.F., Marzen, M., Mingorance, M.D., Ortigosa, L., Peters, P., Regüés, D., Ruiz-Sinoga, J.D., Scholten, T., Seeger, M., Solé-Benet, A., Wengel, R., Wirtz, S. 2013a. European small portable rainfall simulators: A comparison of rainfall characteristics. Catena 110, 100-112. http://doi. org/10.1016/j.catena.2013.05.013.

Iserloh, T., Ries, J.B., Cerdà, A., Echeverría, M.T., Fister, W., Geißler, C., Kuhn, N.J., León, F.J., Peters, P., Schindewolf, M., Schmidt, J., Scholten, T., Seeger, M. 2013b. Comparative measurements with seven rainfall simulators on uniform bare fallow land. Zeitschrif für Geomorphology Supplementband 57, 11-26. http://doi.org/10.1127/0372-8854/2012/S-00085.

Kinnell, P.I.A. 2005a. Raindrop-impact-induced erosion processes and prediction: A review. Hydrological Processes 19, 2815-2844. http://doi.org/10.1002/hyp.5788.

Kinnell, P.I.A. 2005b. Sediment transport by medium to large drops impacting flows at subterminal velocity. Soil Science Society of America Journal 69, 902-905. http://doi.org/10.2136/ sssaj2004.0273.

Kinnell, P.I.A. 2001. Particle travel distances and bed and sediment compositions associated with rain-impacted flows. Earth Surface Processes and Landforms 26, 749-758. http://doi. org/10.1002/esp.221.

Kinnell, P.I.A. 1993. Sediment concentrations resulting from flow depth/drop size interactions in shallow overland flow. Transactions of the ASAE 36, 1099-1103.

Kinnell, P.I.A. 1985. Runoff effects on the efficiency of raindrop kinetic energy in sheet erosion. Soil Erosion and Conservation 399-405.

Kirchhoff, M., Rodrigo-Comino, J., Seeger, M., Ries, J.B. 2017. Soil erosion in sloping vineyards under conventional and organic land use managements (Saar-Mosel valley, Germany). Cuadernos de Investigación Geográfica 43 (1), 119-140. http://doi.org/10.18172/cig.3161.

Kleinhans, M.G., Bierkens, M.F.P., van der Perk, M. 2010. HESS Opinions On the use of laboratory experimentation: "Hydrologists, bring out shovels and garden hoses and hit the dirt." Hydrology and Earth System Sciences 14, 369-382. http://doi.org/10.5194/hess-14-369-2010.

Kleinhans, M.G., van Dijk, W.M., van de Lageweg, W.I., Hoendervoogt, R., Markies, H., Schuurman, F. 2010. From nature to lab: scaling self-formed meandering and braided rivers. In: Dittrich, Koll, Aberle, Geisenhainer (eds.), River Flow 2010, pp. 1001-1010. 
Kuhn, N.J., Greenwood, P., Fister, W. 2014. Use of Field Experiments in Soil Erosion Research, in: M.J. Thornbush, C.D. Allen, F.A. Fitzpatrick (Eds.), Developments in Earth Surface Processes, Elsevier, pp. 175-200. http://doi.org/10.1016/8978-0-444-63402-3.00011-X.

Lassu, T., Seeger, M., Peters, P., Keesstra, S.D. 2015. The Wageningen Rainfall Simulator: Set-up and Calibration of an Indoor Nozzle-Type Rainfall Simulator for Soil Erosion Studies. Land Degradation \& Development 26, 604-612. http://doi.org/10.1002/ldr.2360.

Lehmann, P., Hinz, C., McGrath, G., Tromp-van Meerveld, H.J., McDonnell, J.J. 2007. Rainfall threshold for hillslope outflow: an emergent property of flow pathway connectivity. Hydrology and Earth System Sciences 11, 1047-1063.

León, J., Badía, D., Echeverría, M.T. 2015. Comparison of different methods to measure soil erosion in the Central Ebro Valley. Cuadernos de Investigación Geográfica 41 (1), 165-180. http://doi.org/18172/cig.2703.

León, J., Seeger, M., Badía, D., Peters, P., Echeverría, M.T. 2014. Thermal shock and splash effects on burned gypseous soils from the Ebro Basin (NE Spain). Solid Earth 5, 131-140. http://doi. org/10.5194/se-5-131-2014.

Luk, S.H., Cai, Q.G. 1990. Laboratory experiments on crust development and rainsplash erosion of loess soils, China. Catena 17, 261-276. http://doi.org/10.1016/0341-8162(90)90020-E.

Lundin, R. 2001. Auroral particle acceleration processes: the legacy of Hannes Alfvén. Physics and Chemistry of the Earth, Part C: Solar, Terrestrial \& Planetary Science 26, 13-23. http:// doi.org/10.1016/S1464-1917(00)00085-4.

Major, J.J. 1997. Depositional processes in large-scale debris-flow experiments. The Journal of Geology 105, 345-366.

Marzen, M., Iserloh, T., Casper, M.C., Ries, J.B. 2015. Quantification of particle detachment by rain splash and wind-driven rain splash. Catena 127, 135-141. http://doi.org/10.1016/j. catena.2014.12.023.

Masselink, R.J.H., Temme, A.J.A.M., Giménez, R., Casalí, J., Keesstra, S.D. 2017. Assessing hillslope-channel connectivity in an agricultural catchment using rare-earth oxide tracers and random forests models. Cuadernos de Investigación Geográfica, 43 (1), 19-39. http://doi. org/10.18172/cig.3169.

McGregor, K.C., Bengtson, R.L., Mutchler, C.K. 1988. Effects of surface straw on interrill runoff and erosion of Grenada silt loam soil. Transactions of the ASAE 31,111-116.

Mertens, J., Jacques, D., Vanderborght, J., Feyen, J. 2002. Characterisation of the field-saturated hydraulic conductivity on a hillslope: in situ single ring pressure infiltrometer measurements. Journal of Hydrology 263, 217-229. http://doi.org/10.1016/S0022-1694(02)00052-5.

Mueller, E.N., Wainwright, J., Parsons, A.J. 2007. Impact of connectivity on the modeling of overland flow within semiarid shrubland environments. Water Resources Research 43. http:// doi.org/10.1029/2006WR005006.

Mutchler, C.K., McGregor, K.C., Cullum, R.F. 1994. Soil loss from contoured ridge-till. Transactions of the ASAE 37, 139-142. http://doi.org/10.13031/2013.28063.

Navas, A., Garcia-Ruiz, J.M., Machin, J., Lasanta, T., Valero, B. 1997. Soil erosion on dry farming land in two changing environments of the central Ebro Valley, Spain. IAHS Publication 245, 13-20.

Nearing, M.A., Govers, G., Norton, L.D. 1999. Variability in soil erosion data from replicated plots. Soil Science Society of America Journal 63, 1829-1835. http://doi.org/10.2136/ sssaj1999.6361829x.

Okin, G.S., Parsons, A.J., Wainwright, J., Herrick, J.E., Bestelmeyer, B.T., Peters, D.C., Fredrickson, E.L. 2009. Do Changes in Connectivity Explain Desertification? BioScience 59, 237-244. http://doi.org/10.1525/bio.2009.59.3.8.

Okuda, S. 1991. Rapid mass movements, in: Field Experiments and Measurement Programs in Geomorphology. A.A.Balkema, Amsterdam, pp. 61-105. 
Otto, K.H., Mönter, L. 2015. Scientific Literacy im Geographieunterricht fördern. Experimentelle Lehr-/Lernformen und Modellexperimente. Geographie Heute 322, 2-7.

Pavelka, J., Smetanová, A., Rejman, J., Kováčik, P. 2017. An interdisciplinary tillage erosion experiment: Establishing a new field in grasslands with reconstructed ard plough of the Bronze Age. Cuadernos de Investigación Geográfica 43 (1), 101-118. http://doi.org/10.18172/cig.3131.

Paola, C., Straub, K., Mohrig, D., Reinhardt, L., 2009. The "unreasonable effectiveness" of stratigraphic and geomorphic experiments. Earth-Science Reviews 97, 1-43. http://doi. org/10.1016/j.earscirev.2009.05.003.

Poesen, J.W.A., Lavee, H. 1991. Effects of size and incorporation of synthetic mulch on runoff and sediment yield from interrils in a laboratory study with simulated rainfall. Soil and Tillage Research 21, 209-223. http://doi.org/10.1016/0167-1987(91)90021-O.

Postma, G., Kleinhans, M.G., Meijer, P.T., Eggenhuisen, J.T. 2008. Sediment transport in analogue flume models compared with real-world sedimentary systems: a new look at scaling evolution of sedimentary systems in a flume. Sedimentology 55, 1541-1557. http://doi.org/10.1111/ j.1365-3091.2008.00956.x.

Radder, H. 2009. The philosophy of scientific experimentation: a review. Automated Experimentation 1, 2. http://doi.org/10.1186/1759-4499-1-2.

Reguiés, D., Badía, D., Echeverría, M.T., Gispert, M., Lana-Renault, N., León, J., Nadal-Romero, E., Pardini, G., Serrano-Muela, P. 2017. Analysing land uses and vegetation cover effect on soil infiltration in three contrasting environments in Northeast Spain. Cuadernos de Investigación Geográfica 43 (1), 141-169. http://doi.org/10.18172/cig.3164.

Ries, J.B. 1994. Bodenerosion in der Hochgebirgsregion des östlichen Zentral-Himalaya untersucht am Beispiel Bamti/Bhandar/Surma, Nepal. Universität Freiburg, Freiburg i. Br.

Ries, J.B., Iserloh, T., Seeger, M., Gabriels, D. 2013. Rainfall simulations constraints, needs and challenges for a future use in soil erosion research. Zeitschrif für Geomorphology Supplementband 57, 1-10. http://doi.org/10.1127/0372-8854/2013/S-00130.

Ries, J.B., Seeger, M., Iserloh, T., Wistorf, S., Fister, W. 2009. Calibration of simulated rainfall characteristics for the study of soil erosion on agricultural land. Soil and Tillage Research 106, 109-116. http://doi.org/10.1016/j.still.2009.07.005.

Rodrigo-Comino, J., Brings, C., Lassu, T., Iserloh, T., Senciales, J.M., Martínez Murillo, J.F., Ruiz Sinoga, J.D., Seeger, M., Ries, J.B. 2015. Rainfall and human activity impacts on soil losses and rill erosion in vineyards (Ruwer Valley, Germany). Solid Earth 6, 823-837. http://doi. org/10.5194/se-6-823-2015.

Rodrigo-Comino,J., Seeger, M., Senciales, J.M., Ruiz-Sinoga. J.D., Ries, J.B. 2016. Variación espacio-temporal de los procesos hidrológicos del suelo en viñedos con elevadas pendientes (Valle del Ruwer-Mosela, Alemania). Cuadernos de Investigación Geográfica 42 (1), 281 306. http://doi.org/10.18172/cig. 2934.

Seeger, M. 2007. Uncertainty of factors determining runoff and erosion processes as quantified by rainfall simulations. Catena 71, 56-67. http://doi.org/10.1016/j.catena.2006.10.005.

Seuffert, O. 1993. Die Bodenerosion als ökologischer Faktor und als wissenschaftliches Problem. Petermanns Geographische Mitteilungen 137, 259-274.

Seyhan, E. 1977. Essential conditions of rainfall simulation for laboratory water erosion experiments. Earth Surface Processes 2, 185-190. http://doi.org/10.1002/esp.3290020210.

Shinbrot, T., Duong, N.H., Kwan, L., Alvarez, M.M. 2004. Dry granular flows can generate surface features resembling those seen in Martian gullies. PNAS 101, 8542-8546. http://doi. org/10.1073/pnas. 0308251101.

Shriner, D.S., Abner, C.H., Mann, L.K. 1977. Rainfall simulation for environmental application. Oak Ridge National Lab., TN (USA). 
Sidiras, N., Roth, C.H. 1987. Infiltration measurements with double-ring infiltrometers and a rainfall simulator under different surface conditions on an Oxisol. Soil and Tillage Research 9, 161-168. http://doi.org/10.1016/0167-1987(87)90082-1.

Sidorchuk, A., Schmidt, J., Cooper, G. 2008. Variability of shallow overland flow velocity and soil aggregate transport observed with digital videography. Hydrological Processes 22, 4035 4048. http://doi.org/10.1002/hyp.7006.

Šimůnek, J., Wendroth, O., van Genuchten, M.T. 1999. Estimating unsaturated soil hydraulic properties from laboratory tension disc infiltrometer experiments. Water Resources Research 35, 2965-2979. http://doi.org/10.1029/1999WR900179.

Slattery, M.C., Bryan, R.B. 1994. Surface seal development under simulated rainfall on an actively eroding surface. Catena 22, 17-34. http://doi.org/10.1016/0341-8162(94)90063-9.

Slaymaker, O. 1991a. Introduction. In: Field Experiments and measurement programs in Geomorphology. A.A.Balkema, Amsterdam, pp. 1-5.

Slaymaker, O. 1991b. Field experiments and measurement programs in Geomorphology. A.A. Balkema, Rotterdam.

Slaymaker, O., Dunne, T., Rapp, A. 1982. The nature of field experiments in geomorphology. Studia Geomorphologica Carpatho-Balcanica 11-17.

Smets, T., Poesen, J., Bochet, E. 2008. Impact of plot length on the effectiveness of different soilsurface covers in reducing runoff and soil loss by water. Progress in Physical Geography 32, 654-677. http://doi.org/10.1177/0309133308101473.

Stroosnijder, L. 2005. Measurement of erosion: Is it possible? Catena 64, 162-173. http://doi. org/10.1016/j.catena.2005.08.004.

Todisco, F., Vergni, L., Mannocchi, F., Bomba, C. 2012. Calibration of the soil loss measurement method at the Masse experimental station. Catena 91, 4-9. http://doi.org/10.1016/j. catena.2011.02.003.

Védie, E., Costard, F., Font, M., Lagarde, J.L. 2008. Laboratory simulations of Martian gullies on sand dunes. Geophysical Research Letters 35. http://doi.org/10.1029/2008GL035638.

Vermeulen, B., Boersema, M.P., Hoitink, A.J.F., Sieben, J., Sloff, C.J., van der Wal, M. 2014. River scale model of a training dam using lightweight granulates. Journal of Hydro-environmental Research 8, 88-94. http://doi.org/10.1016/j.jher.2013.05.004.

Wallerstein, N.P., Alonso, C.V., Bennett, S.J., Thorne, C.R. 2001. Distorted Froude-scaled flume analysis of large woody debris. Earth Surface Processes and Landforms 26, 1265-1283. http://doi.org/10.1002/esp.271.

Wishmeier, W.H., Smith, D.D. 1978. Predicting Rainfall Erosion Losses: A Guide to Conservation Planning. Agriculture Handbook, USDA/Science and Education Administration, US. Govt. Printing Office, Washington, D.C.

Wollny, E. 1879. Forschungen auf dem Gebiete der Agrikultur-Physik. Carl Winter's Universitätsbuchhandlung.

Zemke, J. 2017. Set-up and calibration of a portable small scale rainfall simulator for assessing soil erosion processes at interrill scale. Cuadernos de Investigación Geográfica 43 (1), 63-81. http://doi.org/10.18172/cig.3129. 